\title{
Coordinated market economy/ liberal employment relations: low cost competition in the German aviation industry
}

\section{Michael Barry and Werner Nienhueser*}

\begin{abstract}
This paper examines the German low cost airline industry by analyzing how the growth of low cost competition has influenced the industry's pattern of employment relations. The paper highlights the role of Lufthansa, as both the traditional flag carrier and the leading site of employment relations within the German aviation sector. The paper explains how Lufthansa has positioned itself to face low cost competition by, among other initiatives, creating its own low cost subsidiary (Germanwings). Competitive pressures, stemming from the liberalization of European aviation and demand for low cost travel, have produced a marked divergence in this industry from the typical pattern of German employment relations. The paper explains this divergence by situating the case study within the varieties of capitalism literature.
\end{abstract}

Keywords Varieties of Capitalism, employment relations, low cost competition

\footnotetext{
* Michael Barry, Department of Employment Relations, Griffith Business School, Griffith University, Nathan, Queensland, Australia (e-mail: m.barry@griffith.edu.au); Werner Nienhueser, Department of Economics, University of Duisburg-Essen, Essen, Germany (e-mail: werner.nienhueser@uni-due.de).
} 


\section{Introduction}

Debates about convergence and divergence have been central to the scholarly fields of employment relations (ER) and comparative politics in recent decades. A key ongoing debate in comparative ER is whether the forces of globalization are making once distinct national ER practices and institutions appear increasingly homogenous (Berger and Dore, 1996; Bamber, Lansbury and Wailes, 2004). The globalization thesis holds that national systems are converging towards a neo-liberal model characterized by various forms of employment flexibility, reductions in core labour standards, de-centralised bargaining structures, and weaker forms of employee representation. An alternative perspective, provided by new institutionalists, is that institutions continue to matter, and that the forces of history (so called 'path dependency') and institutions have retarded the common pressures to converge that stem from globalization. Advocates of this view cite national contexts that continue to exhibit high levels of union density (Scandinavia), strong systems of co-determination (Germany), and the maintenance of centralised bargaining (Ireland) (OECD, 2006).

In recent years, the Varieties of Capitalism (VoC) literature has promoted this debate by adding weight to the notion that national level institutions - particularly in industrial relations, training and education and corporate governance - provide competitive advantages which help these institutions and national systems retain their distinctiveness. However, while advocating a neo-institutionalist (national diversity) line, VoC advances the notion of a dualism, by proposing two distinct varieties of capitalism a Liberal Market Economy (LME) and a Coordinated Market Economy (CME). LMEs are characterized by 'market based' industrial/employment relations systems. Such 
economies exhibit characteristics including a pronounced decentralization of bargaining, extensive individualization of employment, various forms of employment flexibility, and competitive HRM practices that enable organizations to respond quickly to fluctuations in current profitability by, for example, instituting redundancies, or poaching labour to build skills and competencies. Conversely, CME nations are characterized by interlocking systems of industrial relations and training and education that work together to take wages out of competition and prevent competitive practices associated with LME contexts, such as layoffs and labour poaching (Hall and Soskice, 2001). By neutralizing competitive tendencies, and by generally providing greater statutory protections against 'employment flexibility', CME contexts can potentially provide greater incentives for individuals and firms to invest in competencies, such as firm specific skills (Thelen, 2001; Hall and Soskice, 2001: 25).

The German system of ER is often cited as a distinctive national model, and in VoC literature it has been used as an exemplar of a CME (Hall and Soskice, 2001). Germany has a dual system of ER regulation, providing at one level strong employee representation (on so called quality of work life issues) through work councils and employee representation on company boards, and at another level it is characterized by industry/regional level collective bargaining over wages and conditions involving interest representation provided by industry-based unions and employer associations.

Given these typical features of German ER, the German civil aviation industry represents an interesting case and a point of departure for such an analysis of ER. Uncharacteristically, ER in the German aviation industry has been conducted on an exclusively enterprise basis, rather than through centralized, industry level bargaining 
reinforced by works level negotiations. The system of aviation interest representation is also unique insofar as German ER is concerned - and this is the case in the works council/codetermination, trade union and employer association spheres. In presenting a case of the German aviation industry, focusing on the low cost sector, this paper fleshes out these apparent anomalies. The paper seeks to explain the significance of these features of the industry, and the tensions created by the application of an uncharacteristic LME type model operating at the industry level, within a CME national context.

In this sense, the paper adds weight to the burgeoning studies that test the original assumptions of the VoC model of employment relations dualism articulated by Hall and Soskice. These critical studies contend that the ideal/typical dualism of the VoC model weakens the analytical capacity of this tool in several ways. For example, such arbitrary distinctions do little to explain the variety of possible types of coordination that do not closely approximate the two VoC models. Thus, by focusing on a particular set of countries - mostly based in Europe and North America - it is claimed the model is limited to describing only characteristics of sets of regional and highly industrialized economies (eg Hay, 2005). Moreover, the notion of a distinct dualism leaves little room for national contexts that exhibit characteristics of both models, or for nations that transition between these dualistic constructions over time (see for example Briggs, 2006 for a discussion of the mis-classification of Australia as an LME).

Given that much of the critique of $\mathrm{VoC}$ is based on theoretical observations that challenge the analytical capacity of the instrument to explain the coordinating mechanisms of macro (national) systems of regulation, this paper is novel in that it seeks 
to shed light on an apparent shortcoming of this approach by focusing on micro level variation, by using a case study of a single industry.

By doing so the paper also complements recent scholarship that addresses an apparent shortcoming of $\mathrm{VoC}$ by examining in more complex detail how competitive pressures and the interests of employment relations actors produce contrary coordinating tendencies within national systems. Thus, in examining employer coordination in Germany, Japan and Sweden, Thelen and Kume (2006) have supported the VoC contention that employer interests are central to understanding how labour relations are coordinated. However they challenge VoC's assumption of a uniformity (or composite) of employer interest, and argue that employer interests need to be disaggregated. In the case of Germany, they identify paradoxical employment relations trends, linked to different types of employer interests. One set of interests, associated mainly with larger firms, reinforces Germany's traditional coordination structures, such as centralized collective bargaining and interest representation, but is being undercut by a simultaneous trend towards greater workplace negotiations that place pressure on the centralized system to continue to deliver its coordinating role. This latter tendency is leading many, mainly smaller, firms to opt out of centrally bargained agreements as well as their employer associations (Thelen and Kume, 2006: 21-27). This paper reinforces this approach by examining how national and international pressures and the preferences of employment relations actors within the aviation industry have prompted a divergence in the pattern of ER from that typically associated with Germany, as a CME national context. 
Finally, while building on recent literature that exposes the ideal/typical LME/CME dualism as an analytical weakness of the VoC approach, it is important to note that the notion of industry level ER structures and practices diverging from national contexts has been previously explored in comparative employment relations scholarship. Locke (1992: 230) for example has argued that industry level employment relations practices in different countries can be considered potentially more similar than the employment relations practices of different industries within the same national contexts. This approach has been built on by authors such as Katz and Darbishire (2000) who have observed both diversity in ER outcomes within countries and similarities in the adoption of ER practices across nations. Yet, according to Katz and Darbishire (2000: 9-14), common pressures to adopt managerial or HRM approaches, such as 'Japanisation' in the Auto industry, are still meditated by national frameworks of regulation so that common pressures to converge - and even the adoption of common ER practices - still produce divergent ER outcomes.

Following this logic, the expansion of low cost aviation could be said to have created pressures for the adoption of the types of market-based regulation that $\mathrm{VoC}$ attributes to LME countries, although varying responses to these pressures could equally be expected to lead to different ER outcomes across regions and within countries. For example, Turnbull, Blyton and Harvey (2004: 291-292) noted that airline responses to the September 2001 crisis varied between Nth America and Europe with a softer form of restructuring evident in European airline responses, reflecting national regulations that provide for greater employee consultation and participation in restructuring. In Europe ER regulation exists at both the national and European levels. For instance, working time 
is regulated by a European Directive (Council Directive 2000/79/EC) and a European Agreement on the Organisation of Working Time of Mobile Staff in Civil Aviation. This agreement was concluded by the Association of European Airlines (AEA), the European Transport Workers' Federation (EFT), the European Cockpit Association (ECA), the European (Regions) Airline Association (ERA) and the International Air Carrier Association (IACA). Through regulations such as this, German low cost carriers are required to adapt not only to the national regulatory context but, also, to the European context which is more liberalized than the German context. Moreover, as the dominant low cost competitors in the European market are based within national regulatory contexts that permit much greater employment relations flexibility than Germany (Ryanair in Ireland and Easyjet in the U.K.), these airlines have an advantage compared with Germany LCAs of being able to more easily adapt to the European context.

The paper has three sections. Following from the discussion above, Section 1 sets the context for the study by examining the drivers for the recent growth of the European low cost airline industry. Section 2 describes the composition of the low cost industry in Germany. Section 3 outlines the pattern of employment relations in the German airline industry. This section highlights the key role played by Lufthansa, and examines how it has sought to respond to low cost competition, in part by creating a separate low cost brand. Employment relations at Lufthansa, it is argued, influence the pattern of employment relations across the industry. Yet, while Lufthansa is the industry pace setter, it has also needed to respond to low cost competition to retain its market share, and thus it is both a catalyst and captive in this regulatory process. This section is divided into 
three subsections dealing respectively with the pattern of collective bargaining, the structure and pattern of interest representation, and the nature of HRM.

Data and information incorporated in this case study were drawn from open interviews with 7 key informants as well as the analysis of company websites and internet discussion boards of flying personnel. We examined a range of sources, including company annual reports, documents obtained from employer associations and trade unions, and secondary sources. The interviews included one pilot, one member of a supervisory board, three trade union officials, one human resource manager, and one research expert in the low cost airline industry.

\section{The context}

Following liberalization of the European aviation market in the late 1990s, the low cost sector recorded dramatic growth and profitability in the early years of the new millennium. This growth occurred despite a series of airline crises including September 11, SARS, and sustained high oil prices. Growth has continued since that time. By 2006 the low cost sector accounted for $24 \%$ of intra-EU capacity (seats available) and for $30 \%$ in 2007 (Route Development Co, 2007; OAG 2007), The records of the European Low Fares Airline Association (ELFAA) also recorded strong growth in passenger numbers among its member firms, from 106 to 140 million in a two year period until June 2008 (http://www.elfaa.com/Statistics_June2008.pdf).

In 2005 Germany was Europe’s second largest aviation market with an 18\% share of all traffic from EU countries. Only the UK had a larger share of air traffic, which can partly be attributed to its island status, and limited competition from land transport. In 
Germany the low cost carriers' share of total passenger miles increased from approximately 5\% in 2001 to $15 \%$ in 2004 .

As in other aviation markets, the growth and success of European LCAs has forced traditional full service carriers to respond. They have done so by adopting characteristics of the low cost model, such as reducing fares on routes where they face direct competition from new entrants. For example, Lufthansa reduced its economy class fare on its Cologne - Hamburg route from €143 restricted to €92 unrestricted when a low cost airline, Hapag Lloyd Express, entered the route in 2003 (ELFAA, 2004: 15). Other responses have included reducing staffing, changing remuneration and reward structures, trimming customer services, and imitating aspects of their low cost competitors' marketing strategies (including progressively adopting on-line bookings). For some traditional carriers, an alternative method of responding to this competition has been to set up their own LCAs. Germany’s flag carrier, Lufthansa, has used a low cost subsidiary, Germanwings, precisely as part of such a strategy. Germanwings was established as a wholly owned subsidiary of Eurowings. In turn, Eurowings is $49 \%$ owned by Lufthansa, which exercises a controlling interest in the company. In January 2009, Germanwings became 100 percent owned by Lufthansa. Through Germanwings, Lufthansa has been able to capture an important share of the price-sensitive aviation market. At the same time, by positioning its subsidiary to compete directly in the low cost market, Lufthansa has been able to preserve its traditional brand identity, which is associated with quality. Indeed, Lufthansa has sought to emulate the likes of BMW and Mercedes by pursuing and preserving a ‘high quality made in Germany’ strategy (Lehrer, 2001: 370). 


\section{Low cost competition in Germany}

There is no single model of low cost competition, overall or within the German aviation industry. In the European market, Ryanair has been the leading low cost carrier, carrying more than 40 million passengers in 2006, increasing to more than 50 million by 2008. In 2006 Ryanair had a market share of $7 \%$ of all European flights and $30 \%$ of low cost flights (Bryan, Garnier and Co, 2007; www.ryanair.com). Ryanair is seen as a prototypical low cost carrier (Alamdari and Fagan, 2005; Pate and Beaumont, 2006: 325) and is used here as a point of comparison for our analysis of German low cost competition, and a benchmark against which we assess Germanwings' operational performance. Ryanair is known for both its adversarial approach to employment relations and its strict management of its cost structure. In 2004 the company announced it would eliminate reclining seats, window blinds, seat headrest covers, and seat pockets. More recently, the company confirmed its plan to close all check-in desks in 2010. Ryanair is known for its hard line approach to labour management and for its refusal to negotiate with or recognise unions. This approach is in contrast to Southwest, the other archetypal low cost airline, which recognises employee choice in representation and bargaining (Gittell, 2003). The employment relations model adopted by Ryanair can be described as 'hard HRM' (Legge, 1995), focussing on cutting labour costs and accepting a higher level of conflict and turnover.

Ryanair is closer to the classic low cost model than any of the German-based low cost carriers, and some argue closer than even Southwest (Alamdari and Fagan, 2005). Not only does Ryanair ruthlessly attack its costs in terms of both labour and customer services, it also flies predominantly to secondary airports, and predominantly flies 'seat 
only’ passengers - defined here as passengers not booked through tour packages. Compared to this classic low cost model, we might say that Germany has a 'mixed' low cost model. Most German LCAs fly both seat only passengers (some business, some leisure) as well as tour package passengers. In contravention to the classic low cost model, German LCAs do not fly exclusively point to point, nor do they fly exclusively to secondary airports.

In 2006 the main German-based LCAs were Air Berlin, Hapag-Lloyd Express, DBA (until 2006), Germanwings and Condor (which had only small market share) (DLR, 2006: 5). These airlines represented different variations of possible low cost models. Air Berlin (which bought DBA in 2006) is Germany's largest LCA carrying approximately 20 million passengers per annum (Air Berlin, 2007). Air Berlin has its own mixed business strategy. Its established brand has operated a predominately tour-based business strategy to popular tourist destinations like Palma De Mallorca. For this market, the company provided services on its flights, including food, dedicated seat selection, and a frequent flyer scheme. In 2002, Air Berlin launched an offshoot called City Shuttle to serve the exclusively low cost, seat only market. In 2006 Air Berlin established an offshore base at London-Stansted, a move the company initiated to 'turn the tables' on Ryanair and easyJet who had earlier directly penetrated the domestic German market (Air Berlin, 2005).

Table 1 Most prominent German and European airlines (2006; in italics German-based airlines)

\begin{tabular}{|l|l|l|l|l|}
\hline & Market share (\%)(1) & Employees (3) & $\begin{array}{l}\text { Passengers } \\
\text { (mio.) (4) }\end{array}$ & $\begin{array}{l}\text { Revenue } \\
\text { (mio.) }\end{array}$ \\
\hline Airlines & Germany & Europe & \\
\hline
\end{tabular}




\begin{tabular}{|l|l|l|l|l|l|}
\hline Dba & 21 & 5 & 720 & 4.3 & 404 \\
\hline Germanwings & 20 & 5 & 792 & 7.1 & 560 \\
\hline Air Berlin & 14 & 4 & $\begin{array}{l}4108 \\
\text { (including dba) } \\
(5)\end{array}$ & 19.7 (with dba) & 1575 \\
\hline Ryanair & 13 & 26 & 3603 & 34.8 & 1433 \\
\hline EasyJet & 12 & 21 & 4859 & 33 & 1488 \\
\hline $\begin{array}{l}\text { Hapag Lloyd } \\
\text { Express } \\
(\text { HLX) (2) }\end{array}$ & 11 & 3 & n/a & 4.4 & $\begin{array}{l}259 \text { (data } \\
\text { for 2005) }\end{array}$ \\
\hline
\end{tabular}

(1) March 2006: to, from and within Germany resp. Europe, Source: OAG 2006 and own calculations. (2) Now operated together with Hapagfly under TUIfly. (3, 4) Source: Company websites and Annual Reports. (5) dba was purchased by Air Berlin in 2006. n/a $=$ no information available.

Another interesting variation of the German low cost market is Hapag Lloyd Express (HLX). HLX has a narrow corporate structure, with very few staff and administration. HLX runs its low cost operation on an ACMI (aircraft, crew, maintenance and insurance) basis. Effectively, the parent company leases its planes and flight crew through its low cost subsidiary, Hapag-Fly. In 2007 HLX merged with Hapagfly into a new company, TUIfly. Both companies together transported about 11 million passengers in 2006 (TUIfly, 2007).

Despite the development of low cost competition in Germany, Lufthansa remains by far the dominant German air carrier. Lufthansa had approximately 108,000 employees in 2008. Lufthansa transported more than 50 million passengers for the first time in 2004, this figure rising to 54 million in 2006, and 70 million passengers in 2008 (Lufthansa, 2005a; 2006; 2008). Lufthansa was privatised during the 1990s, a process that commenced in 1994 and took three years to complete. Prior to and following privatisation, Lufthansa has undergone a process of restructuring that has involved major changes to its overall operations as well as its ER. Corporate restructuring has taken a 
number of forms, including the conversion of business divisions into separate subsidiary businesses that act as subcontractors for important operating functions.

Rather than tackling head on the competitive pressures arising from the emergence of low cost competition, Lufthansa has pursued a different business strategy. The company has maintained its traditional full service carrier fleet and established subsidiaries to compete in other segments of the aviation market. As its low cost subsidiary, Germanwings represents part of this business strategy.

Germanwings' motto is 'fly high, pay low'. Yet, rather than being the lowest cost, Germanwings has sought, in its own words, to provide the best value for money, backed by outstanding reliability and an outstanding on-board products (Eurowings, 2004: 23). Germanwings commenced operations in 2002, and has since shown strong growth. Germanwings conveyed 7.1 million passengers in 2006 rising to 8 million in 2008. The airline flies to more than 60 destinations, including a number of destinations within the largely untapped Central and Eastern European market. In 2008 Germanwings had 1032 employees, an increase from 928 in 2007 and 776 in 2006. Eurowings and Lufthansa provide staff training and maintain the Germanwings fleet and so the bulk of Germanwings’ staff (78\% in 2007) are flying personnel (Germanwings, 2007; Lufthansa, 2008).

In 2006 Germanwings had a 4\% share of the European low cost market (in which Ryanair was the leading carrier with 26\% market share) (Route Development Co, 2006). Compared with Ryanair, Germanwings also had a lower level of labour productivity (roughly 7800 passengers per employee in 2005, compared to 11500 at Ryanair). This differential belied the fact that flight frequency per aircraft per week was roughly the 
same number for both airlines (Route Development Co, 2006). Germanwings also enhanced its efficiency as it grew, by improving its aircraft utilization. Thus, seat load factor rose from 80\% in 2003 to 83\% in 2007 (Bierwirth, 2006, Germanwings, 2007). In 2006 Germanwings and Ryanair offered the lowest average prices of all low cost airlines operating in Germany (Ryanair: 42 Euro, Germanwings: 46 Euro per ticket) (DLR, 2006: 8). ${ }^{1}$ These fares were consistent with the standard benchmark of low fares in the European market.

\section{Employment Relations}

\section{Collective bargaining}

The German airline industry has some unusual characteristics so far as German ER is concerned. In a country known for sectoral level collective bargaining, company level negotiations predominate in this industry. The current bargaining structure is partly a hangover from when Lufthansa was Germany’s state-owned, single industry airline. At that time, Lufthansa negotiated a single (company/industry) agreement with a single union (ÖTV, Gewerkschaft Öffentliche Dienste, Transport und Verkehr, now ver.di, Vereinigte Dienstleistungsgewerkschaft). Given the status of the company as a monopoly, there was no requirement for industrial coordination on the employer side.

As new airlines entered the market they replicated this model, however within the enterprise bargaining framework, the main occupational groups have become represented in separate bargaining units. Thus, in the current environment, there is no sectoral agreement for the industry but rather a series of separate company level collective agreements, for pilots, ground staff and cabin crew. 
Given its size, collective agreements struck at Lufthansa have set the pace for the German airline industry. Through a series of long-term collective agreements with each segment of its workforce, Lufthansa fundamentally reshaped its employment relations to align with its strategy to respond to increased market competition. The involvement of unions in this process has helped to secure a series of agreements that the company would not initiate any compulsory redundancies for its pilots and its 14,000 cabin crew (in the case of the latter, until December 2008). According to Turnbull, et al (2004: 292) the requirement for employers to consult with unions over company restructuring is one of the important differences between the European and North American aviation markets, producing in Europe a softer form of restructuring. In the case of Lufthansa, rationalisation has been achieved through early retirement, non-replacement of leavers, and job sharing (Turnbull, et al, 2004: 294).

However, Lufthansa's agreement not to initiate redundancies has come following major concessions from employees. Airline concession bargaining has been a consequence of a fluctuating business cycle as well as a number of specific crises that have forced airlines to undertake major restructuring (Doganis, 2001). At Lufthansa, a major restructuring occurred in 1992 and included a pay freeze for ground staff, a reduction of co-pilot pay, increased work time flexibility, changes to the bonus system and the introduction of a two-tiered pay system.

In a common response to increased aviation competition, Lufthansa has negotiated to increase the flexibility of its labour and to make its labour costs responsive to changes that are an inherent part of the industry's fluctuating market. It has done so by negotiating long-term deals on labour productivity and by making substantial proportions 
of its negotiated wage settlements contingent on company performance. ${ }^{2}$ These long term concessionary deals, struck during periods of industry crisis, represent a danger for unions, for experience has shown that the airline industry can rebound quickly from crises, such as those experienced in Asia in the wake of SARS, and following the September 2001 terror attacks. Moreover, as more and more airlines have been privatised, unions have come to understand than concession bargaining is an artifact of calls by shareholders for increased returns on capital and that 'it is profitability rather than competitiveness or efficiency that lies at the heart of company demands for wage concessions or calls for co-operation in major restructuring exercises' (Blyton, Martinez Lucio, McGurk and Turnbull, 2003: 21).

Recognition of the fluctuating nature of the airline industry's business cycle has also informed the strategies adopted by German unions to negotiate agreements on wages and working conditions. Thus, having felt that they made substantial concessions in the restructuring of Lufthansa during the early 1990s, the union of airline pilots (Cockpit VC), launched a major 'catch up' campaign in 2001 to improve what it claimed were internationally uncompetitive salaries. In a first for the German industrial relations system, the pilots' union sought to benchmark its Lufthansa salary claim against the pay of pilots working for overseas carriers rather than against others in Germany. The pilots argued for a considerable pay increase, of between 30 and 40\%. VC's campaign drew widespread criticism, including from within the union movement, and particularly from its counterpart airline union ver.di. Ver.di argued that all Lufthansa employees, who had shared equally in the hardship of the earlier company restructuring, should receive comparable wage settlements (Eironline, 2001). Behind ver.di's concern was a realisation 
that a high settlement delivered by a rival union might provoke substantial disquiet among its own more heterogeneous membership.

After backing their campaign with warning strikes as well as 24 hour stoppages, the pilots succeeded in achieving a substantial pay increase (24\%), albeit with a proportion of their pay contingent upon company profitability. This pattern of incorporating contingent pay has been replicated for other Lufthansa staff including 14,000 cabin crew represented by the Independent Union of Flight Attendants (UFO). A four year collective agreement for these workers included a reduction in base pay for new employees as well as a pay freeze for existing staff in the first two years of the agreement. This would to be followed by pay increases that were partly contingent on company performance. The agreement also provided for 'productivity improving' measures including increased time on duty and reduced annual leave.

Thus, it appears Lufthansa has achieved much from its negotiated collective agreements. In the first instance, the introduction of contingent pay represents a significant achievement for a company seeking to secure its viability in a more competitive environment. For Lufthansa, reaching a series of agreements on changes to wages and working conditions with its pilots, cabin and ground staff, involving negotiations with three different unions, has provided a degree of certainty as it develops it long term business strategy. Not only has the company locked in sustainable increases to staff base pay but, also, by incorporating a contingent component the company may, according to circumstances, effectively initiate pay reductions without having to go back to the bargaining table (Eironline, 2001; European Foundation, 2002). 
However, despite these changes, Lufthansa's head of Human Resources, Stefan Lauer, warned 'given the difficult outlook for our industry, which is beset by high fuel prices and aggressive competitors, we will be forced to continue to steadily improve our costs and productivity in all areas of the company' (Lufthansa, 2005b). To be sure Lufthansa sees the emergence of low cost competition as a reason to continue to focus on its labour costs, both at Lufthansa and Germanwings. Thus, Lufthansa management argues that 'competitive pay settlements specific to each individual business segment are necessary to enable the Company to keep pace with competing airlines, especially the nofrills carriers in Europe’ (Lufthansa, 2005a).

The development of Germanwings represents a clear low cost competitive advantage for Lufthansa (see Table 2 below). Indeed, the employment relationship is regarded by Eurowings as an essential component of its business design. According to Eurowings:

Variability in elements of fixed costs - for example personnel costs - is an essential prerequisite here and can be competitively decisive. Within the collective bargaining agreements for ground and cabin personnel concluded in 2004, we succeeded in making personnel costs even more flexible. Competitive collective bargaining agreements specific to the business segments concerned are essential if we are to withstand the new competition in Europe (Eurowings, 2004: 17).

Table 2 Basic wages for flight attendants; comparison between Lufthansa and LCAs operating in Germany

Monthly wages, basic salary, without additional parts for work at Sundays, nights etc.; Euro)

\begin{tabular}{|l|l|l|}
\hline $\begin{array}{l}\text { Lufthansa (collective agreement 2003, } 7 \text { tiers, only for } \\
\text { continental flights) }\end{array}$ & lowest tier & highest \\
\hline Germanwings (collective agreement 2004; 9 tiers) & 960 & 1660 \\
\hline
\end{tabular}




\begin{tabular}{|l|l|l|}
\hline Dba (2005) & 1250 & $\mathrm{n} / \mathrm{a}$ \\
\hline AirBerlin (2005) & 800 & $\mathrm{n} / \mathrm{a}$ \\
\hline Rynair (2005) & 680 & $\mathrm{n} / \mathrm{a}$ \\
\hline
\end{tabular}

(source: Interviews with trade union representatives, collective agreements. Wages for Germanwings and Lufthansa are seniority-based, with the lowest tier representing starting wages. Wages for Dba, AirBerlin and Ryanair are starting wages. $\mathrm{n} / \mathrm{a}=\mathrm{no}$ information available)

From the discussion above, it is apparent that the pattern of collective bargaining in the German airline industry bears little resemblance to the typical structure of centralized industry bargaining involving single union negotiations and a functionally equivalent coordinated employer response. The system of enterprise bargaining that operates across the industry has delivered outcomes for employers that enable them to meet the challenges of increased domestic and European competition. Importantly, in the case of Germanwings, this bargaining structure has enabled Lufthansa to participate in the low cost sector and to compete for market share without having to replicate its high wage structure. According to one source, Lufthansa management view Eurowings/Germanwings as an important testing ground for employment relations, to see what is possible with regard to concession bargaining and work intensification (Interview). This does not mean that Lufthansa intends to implement such conditions for low cost operations, but rather it suggests a desire to create an environment in which concession bargaining exists as a permanent threat. It is a signal to Lufthansa employees and their unions that it is possible for management to substitute wage intensive routes by low cost carriers in the place of existing arrangements. In 2004 Lufthansa's CEO, Mayrhuber, announced the outsourcing of non-profitable short distance flights to other airlines (like Germanwings) if the trade union (ver.di) would not make far reaching concessions in wage bargaining (Ver.di, 2004). 


\section{Interest representation}

As mentioned, contrary to the 'German model' of ER, the airline industry is not characterized by strong interlocking interest representation in the form of a single industry union and employer association. On the employer side, there is no single association that speaks effectively for the industry. Owing to the system of enterprise bargaining, ER is predominantly handled at the corporate level. Among German-based LCAs, Air Berlin and HLX had belonged to the European Low Fares Airline Association (ELFAA). ELFAA is an organisation that seeks to represent the trade interests of its low cost members, and attempts, in its own words 'to ensure that European policy and legislation promote free and equal competition to enable the continued growth and development of low fares into the future, allowing a greater number of people to travel by air” (http://www.elfaa.com/ ).

In the German aviation industry, employees are organized in an occupational union structure. Ver.di, a union comprising more than 2 million workers, and the former union of public sector employees, represents ground staff, as well as a large proportion of cabin crew (through its affiliated organisation Cabinpower). Since 1969, German pilots have been represented by a separate union, Cockpit (VC), although this organisation has only represented pilots directly in collective bargaining since the late-1990s. The Independent Organisation of Flight Attendants (UFO), an organisation without the official status of a trade union, represents cabin crew, and had some 14,000 members within the Lufthansa group in 2005. 
The multi-union structure of employee representation and the system of companylevel collective bargaining produces a number of tensions within the industry. As mentioned these tensions were most clearly demonstrated during the 2001 pilots' dispute which, despite being formally confined to Lufthansa, had its effects felt throughout the industry. For example, at HLX, the VC had reached a negotiated settlement with a very modest wage outcome but with a number of improvements to pilots' working conditions. However, following the Lufthansa settlement, the rank and file at HLX expressed concern about its low wage settlement, notwithstanding the negotiation of considerable non-wage benefits. Rank and file resentment of the low wage outcome led to the sacking of the HLX VC bargaining team and a new bargaining team being installed (Interview HLX Pilot).

Employee representation is uneven across the German airline industry. Given its size, Lufthansa employs the bulk of the industry's labour, and therefore Lufthansa's employees also represent a large proportion of total union members. For a long time, Air Berlin operated as the only non-union German carrier. There were rumours within the industry that efforts to organise at Air Berlin resulted in employee victimisation. According to one informant, all other airlines would have liked to have seen Air Berlin unionised because there was a feeling that union avoidance allowed the company to cut labour costs so as to reduce some of its fares below those of its competitors. On the other hand, according to the same source, the other companies liked the presence of Air Berlin when it came time to negotiate with their own employees (Interview, Pilot). In other words, if relatively large settlements at Lufthansa emboldened employees at other airlines to seek similar outcomes, the presence of a low cost, non-union operator served also to 
dampen employee expectations. ${ }^{3}$ In August 2007 Air Berlin signed its first ever collective agreement with unions representing the airline's pilots and cabin crew. This was the result of the airline's expansion and in particular the acquisition of DBA, a company that had long standing union recognition.

As mentioned, in Germany, employee representation occurs through a dual structure of collective bargaining and company level co-determination. Co-determination plays an important role in the employment relationship. Like all joint-stock companies, airlines (and airports) employing over 2,000 workers must have equal employeemanagement representation at supervisory board level, although in the case of a deadlocked vote the chair (always a management representative) holds the deciding vote. Companies with more than 500 employees must have one-third employee representation on supervisory boards. In 2006 Germanwings reached this threshold by employing for the first time more than 500 employees (see Table 3). Representation on supervisory boards can be said to improve employee knowledge of an organisation and its operations. During negotiations over wages and conditions such knowledge can inform bargaining strategies. On the other hand, co-determination also gives the organisation an opportunity to bring employee representatives into closer partnership. Thus, employee representatives may find themselves in the position of selling to their members the 'business case' for low wage outcomes and changes to working conditions (Interview).

Table 3 Firm and company level employee representation

\begin{tabular}{|l|l|l|l|}
\hline & $\begin{array}{l}\text { Works Council (firm } \\
\text { level) } \\
\text { ground personnel for }\end{array}$ & $\begin{array}{l}\text { Staff Council } \\
\text { (Personalvertretung) } \\
\text { (firm level, for flying } \\
\text { personnel) }\end{array}$ & $\begin{array}{l}\text { Co-determination at } \\
\text { the supervisory } \\
\text { board (company } \\
\text { level) }\end{array}$ \\
\hline Lufthansa & Yes & $\begin{array}{l}\text { Yes (50 \% employee } \\
\text { representatives) }\end{array}$ \\
\hline
\end{tabular}




\begin{tabular}{|l|l|l|l|}
\hline Eurowings & Yes & Yes & $\begin{array}{l}\text { Yes (1/3 of the seats } \\
\text { in the supervisory } \\
\text { board) }\end{array}$ \\
\hline Germanwings & No & $\begin{array}{l}\text { Yes (one for cabin } \\
\text { crew, one for cockpit } \\
\text { crew) }\end{array}$ & $\begin{array}{l}\text { (Since 2006, when } \\
\text { Germanwings first } \\
\text { employed >500 } \\
\text { employees) }\end{array}$ \\
\hline
\end{tabular}

As with collective bargaining, there is also considerable variation in employee interest representation across the German airline industry. A comparison of Lufthansa and Germanwings is instructive in this respect. Lufthansa is an established airline with a relatively old workforce. The workforce at Lufthansa exhibits a strong sense of collectivism and this is reflected in strong codetermination in its supervisory board, and through works council representation for its ground staff. Here, it is important to note that the Works Council Constitution Act 1972 contains a special provision for flying personnel, such that they cannot form a work council (Betriebsrat) but a staff council (Personalvertretung) can be formed where there is agreement between the relevant trade union and management. The codetermination rights of a staff council are weaker than those of a Works Council inasmuch as they are restricted to consultation and information rights only. This legal provision partly explains why there is a segmentation of employee interest representation in this sector.

At Germanwings there has been employee representation at Supervisory Board level since 2006 when the airline first employed more than 500 workers. However, there is no Works Council, which would be possible for the ground personnel. Germanwings has two staff councils (or Personalvertretungen); one for the cabin crew and one for the pilots. 
This weaker form of employee workplace representation - compared to Lufthansa where a Works Council for ground personnel exists - partly reflects the fact that Germanwings has a relatively young workforce, many of whom first commenced employment at the firm. Among some of these employees there is a view that there is no need for a works council. However there is also a view that the company promotes a social climate of individualism, and that management opposes proposals to form a works council. One informant explained:

There is a climate of fear [at Germanwings]. The management communicates very clearly: 'We do not need a 'Works Council'. Why? They say that restricts us, all those works agreements. (Interview)

Also, as mentioned, Germanwings has very few of its own technical staff as its aircraft are maintained by Lufthansa and Eurowings. Among aviation industry workers, it is these maintenance and technical staff who tend to support most strongly the establishment of structures of interest representation.

\section{Human resource management}

With the liberalization of the European aviation industry, which has created a highly competitive market for low cost air travel, there have developed tensions in the application of HRM (as well as ER) practice. Germanwings, for example, exhibits a mixture of both 'hard' and 'soft' HRM (Legge, 1995). Germanwings pays lower wages than Lufthansa, but considerably higher wages than Ryanair. According to internet discussion groups and interviews with trade union officials, job security is stronger at Germanwings than Ryanair and Air Berlin, with both of these companies generally 
regarded as being much closer than Germanwings to the pure 'low cost model'. Perfomance-related pay is not important at Germanwings whereas at Ryanair the share of performance-related pay to total pay varies between 25 and 50\% (Interview with trade union officials and Eurowings' works council member). Because Germanwings is experiencing rapid growth, there are opportunities for employment and promotion, again softening the application of its HRM.

The mix of both hard and soft HRM is also apparent in Germanwings' approach to its industrial relations. Germanwings does not try to avoid unionization. Codetermination is now a necessary part of its organisation, but, importantly, not part of its culture, especially compared to firms in sectors like the metal industry. Given strong cost competition at the European and national levels, the management of Germanwings does not compare its performance and business model with traditional, national industries but, rather, with international airlines operating in more deregulated legal and political environments. Insofar as there is a strong pressure to reduce labor costs, this pressure is manifest in attempts to contract out, as well as efforts to restrain wages growth.

At present, there is evidence of a tension between the application of traditional German High Performance Work System approach - characterised in particular by internal labor markets and employment security, codetermination and extensive information sharing, selective hiring practices, comparatively high compensation and extensive training (cf. Pfeffer, 1998) - and the tendency to move towards a harsher form of HRM, more generally associated with such carriers as Ryanair or Air Berlin. To this point, this tension has not created major problems for the management of Germanwings. Again, in part this is because employees are comparatively young (especially compared 
to Lufthansa), and their expectations with regard to job security and wage increases are lower than those of older employees. This could change in the future, resulting in greater opportunities for union organization and a greater prospect of industrial conflict. As noted in the introduction, the 'competitive' features of German airline ER and HRM practice are not consistent with the CME employment relations practices typically associated with Germany, which promote standardization across firms so as to take wages out of competition, prevent labour poaching, and to encourage employees, through guarantees of employment security, to invest in firm specific skills. The application of these anomalous ER practices may produce more visible tensions as airlines strive to continue to compete by further lowering their cost structures and by seeking to respond quickly to competitive pressures while retaining an institutional framework that supports codetermination and collective bargaining.

For employers and employees there are both benefits and risks associated with the application of these uncharacteristic structures of bargaining and interest representation. For employers, greater low cost competition increases the tendency for lower pay settlements, particular where the dominant airlines (Ryanair, Air Berlin) pursue the hardest line in negotiations. Bargaining structures that promote differentiation between the various groups of employees can also be said to strengthen the employer's overall bargaining position, as well as enhancing numerical and financial flexibility, and reducing costs. On the other hand, these same structures of bargaining and interest representation enable strong groups of cohesive employees with homogenous interests, particularly airline pilots, to bargain relatively high wages and comparatively better working conditions by using their high level of general and also firm specific human 
capital as a power resource (Harvey and Turnbull, 2006: 332). Bargaining with several trade unions also creates possibilities for high levels of industrial activity and potential conflicts between different groups of employees represented by different trade unions, having different pay and working conditions. This has the potential to be counterproductive for airlines wishing to resolve the types of coordination problems across functional work areas that Gittell (2003) identifies as having been imperative to the success of Southwest Airlines in creating the original low cost model. Moreover, as VoC hypothesizes, a tension will inevitably arise between the benefits of greater numerical flexibility that are associated with LME-type bargaining arrangements and the disadvantage created by these same arrangements as they create a strong disincentive for employers to provide training, and for employees to willingly invest in firm specific skills (see for example Mares, 2003: 242).

\section{Conclusion}

At the beginning of this paper we noted that the debate concerning convergence and divergence of national systems has been and remains central to study of comparative ER. As an important development in this ongoing debate, VoC advances the notion of a disparity, or dual convergence, between two types of political economies, LMEs and CMEs. If national contexts are converging towards different types of political economies, as VoC proposes, we must ask whether these national patterns are reflected in the characteristics of the micro-level political economies that together make up these national systems. To the extent that variations can be identified in the micro foundations of these 
political economies, they may call into question key assumptions on which such analytical models are built.

This paper has noted an apparent contradiction in the employment relations characteristics of the German aviation industry. In this industry, ER practices do not reflect the tendencies of an exemplar CME national context to promote a high level of coordination through non-market relationships, and function so as to 'take wages out of competition'. Instead ER structures are devolved to the establishment level and there are few examples of the types of industrial coordination that are typical of the German model of employment relations.

Arguably these tendencies are an artifact of the exposure of German airlines to an intensely competitive European aviation market. In this market, airlines are not only competing across national boundaries, but also are establishing bases of operation in other countries to more directly compete for market share. There is little question that the preferences of employers in this market context are aligned to ER settings that provide a high degree of flexibility in wages, staffing and labour utilization. These preferences are consistent with the types of ER practices that are characteristic of LME contexts. In this sense the present study reinforces the view of authors such as Thelen and Kume, and Locke (noted earlier), that what matters in explaining variations in patterns of employment relations are the micro-level preferences of ER actors and how these preferences support and/or destabilize (and are supported or destabilized by) established macro political contexts and their associated systems of employment relations. While employer interests especially in the aviation sector exert pressure for movement in the direction of greater labor market flexibility, the German regulatory context, and in 
particular the provision of co-determination rights, constrains the pace of change and extent to which it can be fully implemented, leaving the parties caught uneasily between two competing regulatory tendencies.

\section{Acknowledgements}

We would like to thank the Journal's anonymous referees for their helpful comments on an earlier version of this paper.

\section{Notes}




\section{References}

Air Berlin (2007) Record number of passengers in 2006, http://ir.airberlin.com/saveas.php?filepath=_files/en/\&file=2007_01_09_Record_ number_of_passengers_in_2006_108.pdf.

Air Berlin (2005) Turnabout is fair play: Air Berlin to fly within UK, press release November 2005, www.airberlin.com

Alamdari, F. and Fagan, S. (2005) 'Impact of the adherence to the original low-cost model on the profitability of low-cost airlines', Transport Reviews, 25(3): 377-92.

Bamber G., Lansbury R. and Wailes N. (eds) (2004) International and Comparative Employment Relations, $4^{\text {th }}$ Edition, Allen and Unwin: Sydney.

Berger, S. and Dore, R. (1996) National Diversity and Global Capitalism, Cornell Press, Ithaca: New York.

Bierwirth, A. (2006) Fly high, pay low. Presetation given by Dr. Andreas Bierwirth, Hamburg Aviation Conference, February 23, 2006. http://www.hamburg-aviationconference.de/pdf/present2006/Session1_Dr_Andreas_Bierwirth.pdf.

Bispinck, R. (2001) 'Tarifpolitischer Halbjahresbericht: Eine Zwischenbilanz der Lohnund Gehaltsrunde 2001’ WSI-Mitteilungen, 54(7): 419-25.

Blyton, P. Martinez Lucio, M. McGurk, J. and Turnbull, P. (2003) Contesting Globalisation: Airline Restructuring, Labour Flexibility and Trade Union Strategies, $2^{\text {nd }}$ Edition, International Transport Workers’ Federation, London.

Briggs, C. (2006) 'The Return of Lockouts Down Under in Comparative Perspective: globalization, the state, and employer militancy', Comparative Political Studies, 39(7): 855-79.

Bryan, Garnier and Co. (2007) Low-cost airlines. The sky's the limit!. http://www1.skyeurope.com/EN/Documents/Company_report_LCC_20070319.p df.

Council Directive 2000/79/EC (2000) Council Directive 2000/79/EC concerning the European Agreement on the Organisation of Working Time of Mobile Staff in Civil Aviation, Official Journal of the European Communities, 1.12.2000.

DG TREN (2005) Analysis of the European Air Transport Industry.

DLR - Deutsches Zentrum für Luft- und Raumfahrt (2006) Low Cost Monitor 2/2006. http://www.dlr.de/fw/Portaldata/42/Resources/dokumente/aktuelles/Low_Cost_M onitor_II_2006.pdf

DLR - Deutsches Zentrum für Luft- und Raumfahrt (2009a) Low Cost Monitor 1/2006. http://www.dlr.de/fw/Portaldata/42/Resources/dokumente/aktuelles/Low_Cost_M onitor_I_2009.pdf

DLR - Deutsches Zentrum für Luft- und Raumfahrt (2009b) Flugpresanalyse von Low Cost Carriern auf ausgewählten Strecken, http://www.dlr.de/fw/Portaldata/42/Resources/dokumente/aktuelles/Sonderbeitrag _Flugpreisanalyse_11_2008.pdf

Doganis, R. (2001) The Airline Business in the Twenty-First Century, Routledge: London.

European Foundation for the Improvement of Living and Working Conditions (2002) Report on the Aviation sector. An analysis of EIRO articles. Dublin. http://www.eurofound.europa.eu/eiro/other_reports/aviation.pdf. 
Eironline (2001) Lufthansa pilots pay dispute draws to close. http://www.eurofound.europa.eu/eiro/2001/06/feature/de0106226f.htm

ELFAA (2004) Liberalisation of European Air Transport: the benefits of low fares airlines to consumers, airports, regions and the environment, European Low Fares Airline Association: Brussels.

Eurowings Luftverkehrs AG (2004) Annual Report 2004. Dortmund.

Germanwings (2007) Facts and Figures Mai 2007. http://www.germanwings.com/download/Germanwings facts and figures.pdf

Germanwings (2007) German low-cost airline carries more than 600,000 passengers and increases fleet utilisation to 83.3 per cent. http://www.germanwings.com/en/6945.html

Gittell, J. Hoffer (2003) The Southwest Airlines Way, Using the Power of Relationships to Achieve High Performance, New York: McGraw-Hill.

Hall, P. A., \& Soskice, D. (2001) 'An Introduction to Varieties of Capitalism' in Hall, P and Soskice, D (eds) Varieties of Capitalism: the Institutional Foundations of Comparative Advantage. New York: Oxford University Press.

Harvey, G. and Turnbull, P. (2006) 'Employment Relations, Management Style and Flight Crew Attitudes at Low Cost Airline Subsidiries: the case of British Airways/Go and bmi/bmibaby', European Management Journal, 24(5): 300-37.

Hay, C. (2005) 'Two can play at that game ... or can they? Varieties of capitalism, varieties of institutionalism'. In D. Coates (ed) Varieties of Capitalism, Varieties of Approaches, Palgrave Macmillan: Hampshire

International Transport Workers' Federation (2007): Air Berlin seals first collective agreements with pilots, cabin crew. http://www.itfglobal.org/campaigns/airberlin.cfm

Katz, H.C., and Darbishire, O. (2000) Converging Divergences: Worldwide Changes in Employment Systems. Ithaca: Cornell University Press.

Legge, K. (1995) Human Resource Management: Rhetorics and Realities, Macmillan Business: London.

Lehrer, M. (2001) 'Macro-varieties of Capitalism and Micro-variations of Strategic Management in European Airlines', in Hall, P. and Soskice, D. (eds) Varieties of Capitalism: the Institutional Foundations of Comparative Advantage. New York: Oxford University Press.

Locke, R. (1992) 'The Demise of the National Union in Italy; Lessons for Comparative Industrial Relations Theory', Industrial and Labor Relations Review, 45(2): 22949.

Lufthansa (2005a) Deutsche Lufthansa AG Financial Statements 2004.

Lufthansa (2005b) Pay agreement reached for cabin crew until end of 2008. Press Release 10.05 .05

Lufthansa (2006) Annual Report 2006. Frankfurt/M.

Lufthansa (2008) Annual Report 2008. Frankfurt/M.

Mares, I. (2003) 'The Sources of Business Interest in Social Insurance: Sectoral versus National Differences', World Politics, 55(2): 229-58.

OECD (2006) OECD employment outlook: Boosting Jobs and Incomes. Paris. 
Pate, J. and Beaumont, P. (2006) 'The European Low Cost Airline Industry: The Interplay of Business Strategy and Human Resources', European Management Journal, 24(5): 322-29.

Pfeffer, J. (1998): The Human Equation: Building Profits by Putting People First. Harvard Business School Press: Boston, Mass.

Route Development Co (2006) SRS Low Cost Monitor 2006. Leicester.

Süddeutsche Zeitung (2007) Pilotengewerkschaft will Tarifvertrag für Air Berlin durchsetzen. $\quad$ http://www.finanznachrichten.de/nachrichten-2007-05/artikel8337025.asp (31.05.2007)

Thelen, C. (2001) 'Varieties of Labor Politics in the Developed Democracies', in Hall, P and Soskice, D (eds) Varieties of Capitalism: the Institutional Foundations of Comparative Advantage, New York: Oxford University Press.

Thelen, C. and Kume, I. (2006) 'Coordination as a Political Problem in Coordinated Market Economies', Governance, an International Journal of Policy, Administration and Institutions, 19(1): 11-42.

TUIfly (2007): Neuer Airlineverbund TUIfly mit Passagierrekord für 2006 / HLXBeförderungsleistung stieg in 2006 um 22 Prozent. Presse-Information 15.01.2007. http://www.tuifly.com/de/service/pressecenter_13472.html.

Turnbull, P. Blyton, P. and Harvey G. (2004) 'Cleared for Takeoff? Management-Labour Partnership in the European Civil Aviation Industry', European Journal of Industrial Relations, 10(3): 287-308.

Ver.di (2004) Tarifinformationen für die Beschäftigten im Lufthansa - Konzern: Lufthansa droht mit Billigjobs. Lufthansa fordert weitreichende tarifliche Zugeständnisse.

http://verkehr.verdi.de/luftverkehr/lufthansa/lufthansa_ag/konzern_berlin_14_06 _2004.

${ }^{1}$ In 2009 more than 50 percent of the average fare are between 60 and 100 Euro (DLR 2009: 5). The average fare for Germanwings is 108 Euro, for Ryanair 47 Euro (DLR 2009b: 3).

2 The Company's collective agreement for ground personnel and flight attendants includes a bonus of $10 \%$ of one monthly salary related to the performance of the company. Performance related pay for pilots covers $20 \%$ of the yearly basic salary (Bispinck 2001:423f).

${ }^{3}$ In May 2007 Cockpit (VC) commenced a campaign to bargain a collective agreement with Air Berlin. The pilot's union views Air Berlin's acquisition of dba as a means to incorporate collective belonging (from dba) into Air Berlin (Süddeutsche Zeitung 2007). 